\title{
A Prospective Study of Profile of Agricultural Orthopaedic Injuries in North India in a Tertiary Care Centre
}

\author{
Singh R. ${ }^{1}$, Arora K. ${ }^{2}$, More $\mathrm{H}^{3}{ }^{*}$, Kaur K. ${ }^{4}$, Khanna M. ${ }^{5}$, Delair A. ${ }^{6}$ \\ DOI: https://doi.org/10.17511/ijmrr.2021.i03.07
}

1 Roop Singh, Department of Orthopaedics, Pt BD Sharma PGIMS, Rohtak, Haryana, India.

2 Kunal Arora, Department of Orthopaedics, Pt BD Sharma PGIMS, Rohtak, Haryana, India.

3* Hemant More, Department of Orthopaedics, Pt BD Sharma PGIMS, Rohtak, Haryana, India.

${ }^{4}$ Kiranpreet Kaur, Department Anaesthesia, Pt BD Sharma PGIMS, Rohtak, Haryana, India.

5 Mohit Khanna, Department of Orthopaedics, Pt BD Sharma PGIMS, Rohtak, Haryana, India.

${ }^{6}$ Anas Delair, Department of Orthopaedics, Pt BD Sharma PGIMS, Rohtak, Haryana, India.

Background: Over time agriculture has transformed into an industry, both in scale and mechanization. Growing demand for agricultural yield and increasing mechanization has led to growth in the numbers of agricultural accidents and injuries causing significant morbidity and economical loss. Aim: To study the causes, patterns, outcomes of injuries due to agricultural accidents, their effect on the productivity of the victims, and to suggest possible remedial measures, a prospective study was undertaken. Methods: A total of 106 patients reporting agricultural injuries (AI) over 14 months in 2019-20 were enrolled and data was recorded on a pre-structured proforma. Results: With the preponderance of male victims, educational status, skill levels, lighting \& climatic conditions, intoxication and fatigue were found to be major determinants in the causation of injuries with upper limbs being the predominantly involved part (75.47\%) and most of the cases ended up requiring some form of surgery $(88.68 \%)$. Agricultural machinery $(56.60 \%)$ was the main cause of AI and Chaff Cutter Machine caused the maximum AI (37.73\%). Amputations were the most common injuries sustained $(47.16 \%)$. Agricultural injuries affected the range of motion of body parts $(32.07 \%)$ and work $(58.49 \%)$ \& household activities (49.05\%); thus impairing work efficiency and economy. Conclusion: The present study highlights the need for a robust surveillance and data analysis leading to better design of farming machinery and equipment, more relevant education and training systems, stronger legislations as well as a comprehensive rehabilitative program aimed at reducing the socio-economic burden caused by agricultural injuries.

Keywords: Agricultural injuries, Farming machinery, Amputation

Corresponding Author

Hemant More, Department of Orthopaedics, Pt BD Sharma PGIMS, Rohtak, Haryana, India.

Email: drmore@gmail.com
How to Cite this Article

Singh R, Arora K, More H, Kaur K, Khanna M, Delair A. A Prospective Study of Profile of Agricultural Orthopaedic Injuries in North India in a Tertiary Care Centre. Int J Med Res Rev. 2021;9(3):172-180. Available From

https://ijmrr.medresearch.in/index.php/ijmrr/article/ view/ 1275
To Browse

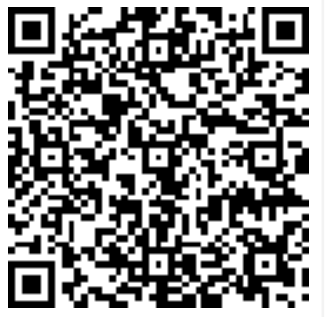

Manuscript Received 2021-05-01

Conflict of Interest No
Review Round 1 2021-05-03

Funding

Nil

Review Round 2
2021-05-09
Ethical Approval
Yes

Review Round 3 2021-05-19

Plagiarism X-checker $8 \%$
Accepted 2021-05-27

Note

(c) 2021 by Roop Singh, Kunal Arora, Hemant More, Kiranpreet Kaur, Mohit Khanna, Anas Delair and Published by Siddharth Health Research and Social Welfare Society. This is an Open Access article licensed under a Creative Commons Attribution 4.0 International License https://creativecommons.org/licenses/by/4.0/ unported [CC BY 4.0]. 


\section{Introduction}

Agriculture is one of the oldest occupations in human history spanning millennia and civilizations. Originally meant for providing a nutritional supplement to the staple diet of hunted wild game, agriculture was limited to growing crops with basic tools and catering to a family or small group. With time, newer tools and techniques developed and took agriculture beyond local needs. With a rising population and resultant increasing global demand for food grain along with mechanization and commercialization of agriculture, it slowly metamorphosed into an industry. Agriculture as an industry is not only one of the most critical fields globally as it feeds mankind; it also employs a sizeable proportion of populations around the world. While agriculture has grown and evolved as an industry with ever-increasing efficiency of production and development of more complex farming machines, at the same time there has also been increasing incidents of agriculture-related injuries. The agricultural business is considered as one of the most hazardous sectors in both developing and developed countries with high rates of accidental deaths, injuries, and work-related illnesses. [1,2]. Agricultural injuries are thus associated with a significant financial burden on the individual as well as the healthcare system and also results in substantial physical and psychological morbidity of those affected. Agriculture-related injuries have high frequency and mortalitymorbidity rates. However, the exact figures are grossly underestimated due to inadequate, imprecise, and heterogeneous recording and notification systems. As a result, the real picture of occupational health and safety of farm workers is likely to be worse than what official statistics indicate. Eventually, the preventive and rehabilitative ecosystem developed by the authorities that are based on the available data remains grossly inadequate to the real requirement of the agricultural sector.

India is the largest producer of pulses and the second-largest producer of wheat and rice in the world. [3]. Located in Northern India, the state of Haryana, with a population of about 25.35 million as per the 2011 census, has a geographical area of 44,212 square kilometres with $80 \%$ area under cultivation. $[4,5]$. It is the fourth highest wheat producing state in India. [6]. Farm mechanization has resulted in the extensive use of wheat threshers and combine-harvesters, etc.
On our farms with a resultant increase in agricultural injuries. Injuries due to threshers are mostly of the upper limb and result in significant morbidity. In our setting, agriculture is largely family owned-family run activity, thereby involving a fairly large number of children in the farming activities. Children are particularly prone to severe hand and upper extremity injuries and machinery related limb amputations, which require multiple surgical procedures and weeks of hospital stay for limb-threatening injuries.[7]. If physical, psychological and economic fallout from agricultural injuries is to be reduced, we need to analyze agricultural injuries. This study has compiled and assessed information on agricultural Orthopaedic injuries in a tertiary care Centre in North India. We have also analyzed the injury trends, their severity and available preventive, curative and rehabilitative interventions.

\section{Material and methods}

A total of 106 patients with agricultural injuries (AI) who attended the Accident and Emergency department from February 2019 to March 2020 were enrolled in the study. Various parameters like socio-demographic data, injury-related characteristics, mode of injury, type of injury, body part injured, the time gap between injury and presentation, type of farmer, duration of work, intoxication and type of management were assessed in the study. Upper limb, lower limb, pelvic and spine injuries in subjects of all age groups involved in agricultural activities were included. Road traffic accidents, Suicide or parasuicide with agricultural equipment, Snakebites, and Physical assault were excluded from the study. The magnitude of agriculture injury was calculated concerning total acute trauma cases coming to accident and emergency in the Department of Orthopaedics, of a tertiary care centre in the state of Haryana in North India. The risk factors and their association with agricultural injury were identified. Analysis was also done to identify the correlation of different age groups, sex, agricultural activity, time and agricultural tool with agriculture injury. Patients included in the study were followed up at 2 nd week, one month, 3 months and 6 months and wound status, fracture union, range of motion of injured body part, the effect of injury on daily household activity and performance after resuming work were recorded and outcome of the patient was noted. Pre-structured subjects proforma was used for data collection. 
Descriptive statistics were analyzed with SPSS version 20 software. Continuous variables were presented as mean \pm SD. Categorical variables were expressed as frequencies and percentages. The Pearson's chi-square test or the chi-square test of association was used to determine if there is a relationship between two categorical variables. $\mathrm{P}<0.05$ was considered statistically significant.

\section{Results}

Table 1 shows the age and gender distribution of the study population. There was no difference in the age of male and female patients ( $p$ value=0.703). The mean age of the cohort was $36.45 \pm 17.62$ years. Maximum patients were in the age group of 30-45 years. The minimum incidence of AI was seen in patients aged $>60$ years. A significant number $13(12.26 \%)$ of patients were under the age of 18 years. The number of patients in the 0-5 year age group was $5(4.71 \%)$. Male preponderance was observed with a male to female ratio of $3.41: 1$.

Table-1: Age-Gender wise distribution in the study population $(\mathrm{N}=106)$

\begin{tabular}{|c|c|c|c|c|c|c|c|}
\hline \multirow{2}{*}{ Sr. No. } & \multirow{2}{*}{ Age Group (in years) } & \multicolumn{4}{|c|}{ Gender Distribution } & \multirow[t]{2}{*}{ Total No. } & \multirow[t]{2}{*}{$(\%)$} \\
\hline & & Male & $\%$ & Female & $\%$ & & \\
\hline 1. & Less than 18 & 9 & 10.98 & 4 & 16.67 & 13 & 12.26 \\
\hline 2. & $18-30$ & 24 & 29.27 & 5 & 20.83 & 329 & 27.36 \\
\hline 3. & $30-45$ & 31 & 37.80 & 8 & 33.33 & 39 & 36.79 \\
\hline 4. & $45-60$ & 10 & 12.20 & 4 & 16.67 & 14 & 13.21 \\
\hline 5. & $>60$ & 8 & 9.75 & 3 & 12.50 & 11 & 10.38 \\
\hline \multicolumn{2}{|l|}{ Total } & 82 & 100 & 24 & 100 & 106 & 100 \\
\hline \multicolumn{2}{|c|}{ Mean Age ( \pm S.D.) Years } & \multicolumn{2}{|c|}{$36.1 \pm 16.35$} & \multicolumn{2}{|c|}{$57.67 \pm 21.79$} & \multicolumn{2}{|c|}{$36.45 \pm 17.62$} \\
\hline \multicolumn{2}{|c|}{ Range (years) } & \multicolumn{4}{|c|}{ 3-87 years } & & \\
\hline
\end{tabular}

Table 2: Sociodemographic characteristics of the study population $(\mathrm{N}=106)$

\begin{tabular}{|c|c|c|}
\hline Characteristic & $\begin{array}{c}\text { Number of } \\
\text { patients }\end{array}$ & Percentage \\
\hline \multicolumn{3}{|l|}{ Educational Status } \\
\hline Illiterate & 40 & $37.74 \%$ \\
\hline Primary and Middle & 35 & $33.01 \%$ \\
\hline High School & 28 & $26.41 \%$ \\
\hline Graduate and Post Graduate & 3 & $2.84 \%$ \\
\hline \multicolumn{3}{|l|}{ Occupation } \\
\hline Farmer Labourers Employee & 38111522 & $35.84 \% \quad 10.37 \% \quad 14.15 \%$ \\
\hline Student Housewife & 20 & $20.75 \% 18.87 \%$ \\
\hline \multicolumn{3}{|l|}{ Land holding } \\
\hline Zero & 45 & $42.46 \%$ \\
\hline$</=2$ acres & 20 & $18.86 \%$ \\
\hline 2 to 5 acres & 16 & $15.09 \%$ \\
\hline 5 to 10 acres & 13 & $12.27 \%$ \\
\hline
\end{tabular}

\begin{tabular}{|l|l|l|}
\hline$>10$ acres & 12 & $11.32 \%$ \\
\hline Type of family & 52 & $49.05 \%$ \\
\hline $\begin{array}{l}\text { Nuclear } \\
\text { Joint }\end{array}$ & 54 & $50.95 \%$ \\
\hline
\end{tabular}

Table 2 shows the socio-demographic variables of the study population. Most of the patients (40; $37.74 \%$ ) were illiterate (No formal education). Farmers made up 38 (35.84\%), 26 (24.52\%) were farm labourers and employees while the remaining 42 (39.62\%) were housewives and children/students. Forty-five (42.46\%) patients had no landholding and fifty-four (50.95\%) patients were living in a Joint family. Table 3 shows the distribution of the patients in the study, according to etiology and different associated factors with the agricultural injuries. Machinery used in farming was the main etiological factor causing injury (60; $56.60 \%)$. Most patients sustained injury due to chaff/fodder cutting machine 40 (37.73\%); and followed by thresher 11 (10.37\%). Thirty-five $(33.02 \%)$ patients were unskilled workers at the time of injury. Twenty-one (19.81\%) patients were under the influence of alcohol/drugs while 29 $(27.35 \%)$ patients were fatigued at the time of injury. Eighty-seven patients $(82.07 \%)$ had worked for more than three hours before the injury. Sixtynine $(65.10 \%)$ patients presented in the winter season, Sixty-one $(57.54 \%)$ patients reached hospital within 2 hours of injury, 28 (26.41\%) reported in 2-3 hours, and 17 (16.03\%) reached after 3 hours of injury.

Table 3: Distribution of the patients in the study, according to etiology and different associated factors with the agriculture injuries $(\mathbf{N}=\mathbf{1 0 6})$

\begin{tabular}{|l|l|l|}
\hline \multicolumn{2}{|l|}{ No. of patients } & Percentage (\%) \\
\hline Mode of injury & 60 & $56.60 \%$ \\
\hline Machinery & 19 & $17.92 \%$ \\
Equipment & 21 & $19.82 \%$ \\
Fall & 6 & $05.66 \%$ \\
Animal & \multicolumn{2}{|l|}{} \\
\hline Tools/Machinery & 70 & $37.73 \%$ \\
\hline Chaff Cutter Machine & $6.60 \%$ \\
Kassi/Axe & 7 & $6.60 \%$ \\
Sickle & 2 & $1.8 \%$ \\
Potash & 2 & $1.8 \%$ \\
Harrow & 11 & $10.37 \%$ \\
Thresher & 10 & $9.43 \%$ \\
\hline Tractor related & 19 & $17.93 \%$ \\
\hline Duration of work before the injury & $34.90 \%$ \\
\hline Zero to <3 hrs & 37 & \\
3-6 hrs &
\end{tabular}




\begin{tabular}{|l|l|l|}
\hline $\begin{array}{l}\text { 6-9 hrs } \\
>9 \text { hrs }\end{array}$ & 28 & $26.42 \%$ \\
\hline Type of worker & $20.75 \%$ \\
\hline Skilled & 71 & $66.98 \%$ \\
Unskilled & 35 & $33.02 \%$ \\
\hline Intoxication (alcohol/drugs) & 21 & $19.81 \%$ \\
\hline Yes & 85 & $80.19 \%$ \\
\hline No & \multicolumn{3}{|l|}{} \\
\hline Overwork/Fatigue & 29 & $27.35 \%$ \\
\hline Yes & 77 & $72.64 \%$ \\
\hline No & 30 & $28.30 \%$ \\
\hline Light conditions & 76 & $71.70 \%$ \\
\hline Poor & \multicolumn{3}{|l|}{} \\
\hline Good & 69 & $65.10 \%$ \\
\hline Season of injury & 27 \\
\hline Winter & $25.47 \%$ \\
Summer & $09.43 \%$ \\
\hline
\end{tabular}

Table 4: Distribution according to the type of agricultural injuries sustained in the study population $(n=106)$

\begin{tabular}{|c|c|c|}
\hline Type of injury & No. of patients & Percentage \\
\hline Cut /Puncture & 7 & $6.60 \%$ \\
\hline $\begin{array}{l}\text { Lacerations } \\
\text { - Isolated Lacerations (12) } \\
\text { - Lacerations with combined injuries (28) }\end{array}$ & 40 & $37.73 \%$ \\
\hline $\begin{array}{l}\text { Fractures } \\
\text { - Isolated Fractures (24) } \\
\text { - Fractures with combined injuries (18) }\end{array}$ & 42 & $39.62 \%$ \\
\hline $\begin{array}{l}\text { Amputations } \\
\text { - Isolated Amputation (30) } \\
\text { - Amputation with combined injuries (19) }\end{array}$ & 50 & $47.16 \%$ \\
\hline Other Soft tissue injuries & 7 & $06.60 \%$ \\
\hline
\end{tabular}

Table 4 shows the distribution according to the type of agricultural injuries sustained in the study population. In most of the cases, the upper limb was involved in the form of amputations and fractures (Fig. 1 and Fig. 2).

In the cohort most common injury was upper limb injury (80 patients; $75.47 \%$ ), followed by lower limb injury (19 patients; 17.93\%). Amputation was the most common injury (50 patients; $47.16 \%$ ), followed by fracture (closed/open)/dislocation in 40 patients $(37.62 \%)$.

\section{Figure 1:}

Showing amputation at a distal forearm level in a 50-year-male resulting from the Chaff cutting machine.

Radiograph of the injured part.
Shows picture after revision amputation and secondary wound closure.

Showing follow-up picture at 3 months postoperatively. Healing of the stump has occurred without any complication.

\section{Figure 2.}

A \& b. Classical wheat thresher injury. It shows amputation at the level of proximal hand with grossly contaminated forearm and arm lacerated wounds.

01 . Shows wound status after 14 days of daily debridement, EUSOL wash and daily antiseptic dressing.

02. Skin grafting was done once the wound was healthy. Shows picture of the wounds on 15th postoperative day just before suture removal.

E \& f: Show picture at 1-month post-op. Amputation stump appears healthy, skin graft was well taken up, but left a scar.

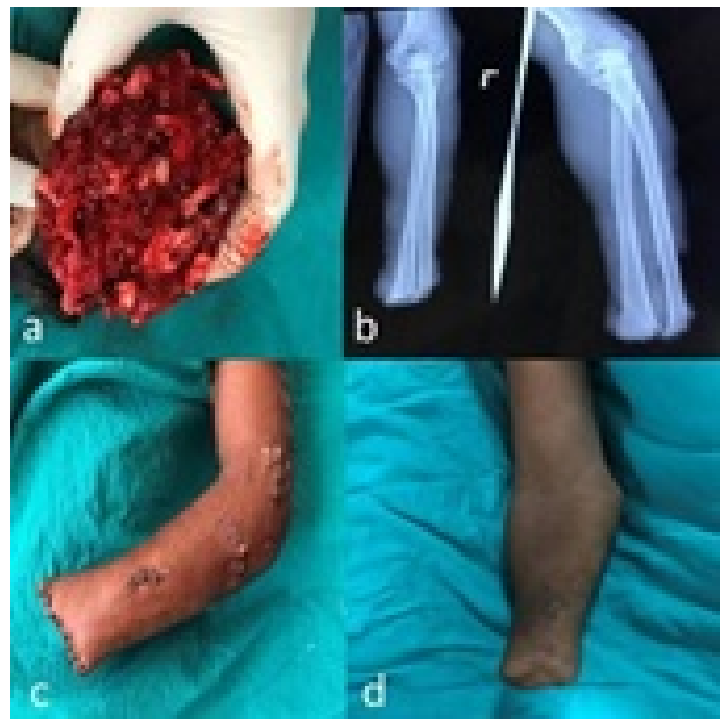

Figure 1

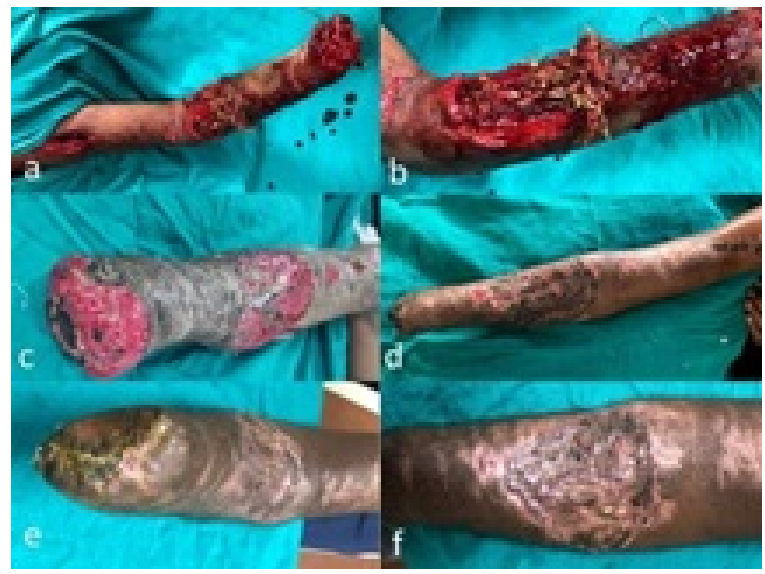

Figure 2 
Table 5: Distribution of patients in the study, according to the different injury characteristics, management, and aftermath of agricultural injuries $(\mathrm{N}=106)$

\begin{tabular}{|c|c|c|}
\hline & No. of Patients & Percentage $(\%)$ \\
\hline \multicolumn{3}{|c|}{ Time is taken to reach the hospital after injury } \\
\hline Within $1 \mathrm{hr}$ & 17 & $16.03 \%$ \\
\hline Within $1-2 \mathrm{hrs}$ & 44 & $41.50 \%$ \\
\hline Within 2-3hrs & 28 & $26.41 \%$ \\
\hline$>3 \mathrm{hrs}$ & 17 & $16.03 \%$ \\
\hline \multicolumn{3}{|l|}{ Part of the body involved } \\
\hline Upper limb & 80 & $75.47 \%$ \\
\hline Lower limb & 19 & $17.93 \%$ \\
\hline Spine & 7 & $06.60 \%$ \\
\hline \multicolumn{3}{|l|}{ Level of amputation } \\
\hline Fingers & 25 & $23.58 \%$ \\
\hline Mid-palm & 15 & $14.15 \%$ \\
\hline Forearm & 4 & $3.77 \%$ \\
\hline Arm & 4 & $3.77 \%$ \\
\hline Foot and leg & 2 & $1.88 \%$ \\
\hline \multicolumn{3}{|l|}{ Management mode } \\
\hline Surgical & 94 & $88.68 \%$ \\
\hline Conservative & 12 & $11.32 \%$ \\
\hline \multicolumn{3}{|l|}{ Surgical management } \\
\hline Wound debridement & 10 & $9.43 \%$ \\
\hline K wire fixation & 23 & $21.69 \%$ \\
\hline Revision amputation & 27 & $25.47 \%$ \\
\hline Nibbling and closure & 15 & $14.15 \%$ \\
\hline External fixator application & 03 & $2.83 \%$ \\
\hline Antiseptic dressings & 24 & $22.64 \%$ \\
\hline Skin grafting & 03 & $2.83 \%$ \\
\hline LAMA & 1 & $0.94 \%$ \\
\hline \multicolumn{3}{|l|}{ Fracture union } \\
\hline Union & 32 & $80 \%$ \\
\hline Mal-union & 02 & $5 \%$ \\
\hline Non-union & 03 & $7.5 \%$ \\
\hline Lost to follow up & 02 & $5 \%$ \\
\hline Expired & 01 & $2.5 \%$ \\
\hline \multicolumn{3}{|l|}{ Wound status } \\
\hline Healed without infection & 84 & $89.36 \%$ \\
\hline Infected & 08 & $8.52 \%$ \\
\hline Lost to follow up & 02 & $2.12 \%$ \\
\hline \multicolumn{3}{|c|}{ Effect on range of motion after injury } \\
\hline Decreased & 34 & $32.07 \%$ \\
\hline Normal & 69 & $65.09 \%$ \\
\hline Lost to follow up & 02 & $01.89 \%$ \\
\hline Expired & 01 & $0.95 \%$ \\
\hline \multicolumn{3}{|c|}{ Effect on work performance after injury } \\
\hline Decreased & 62 & $58.49 \%$ \\
\hline Normal & 41 & $38.68 \%$ \\
\hline Lost to follow up & 02 & $01.88 \%$ \\
\hline Expired & 01 & $0.95 \%$ \\
\hline
\end{tabular}

\begin{tabular}{|l|l|l|}
\hline Effect on household activity after injury \\
\hline Decreased & 52 & $49.05 \%$ \\
Normal & 51 & $48.11 \%$ \\
Lost to follow up & 02 & $01.88 \%$ \\
Expired & 01 & $0.94 \%$ \\
\hline Mortality & 01 & $0.94 \%$ \\
\hline
\end{tabular}

Table 5 shows the distribution of patients in the study, according to the different injury characteristics, management, and aftermath of agricultural injuries. The upper limb was involved most commonly and common injuries were amputations at different levels. The most common level of amputation was at fingers, which were present in 25 patients $(23.58 \%)$. Ninety four $(88.68 \%)$ patients required surgical intervention and $12(11.32 \%)$ were managed conservatively. Conservative management was mainly done in form of crepe bandage, POP cast and medical therapy for back pain patients in the form of NSAIDs and muscle relaxants. Revision amputation was the most common (27 patients; 25.47\%) surgical intervention required, K-wire fixation of fractures was done in $23(21.69 \%)$ patients and wound debridement was done in 10 patients and 3 patients $(2.83 \%)$ underwent skin grafting (Fig. 2). Household activities were decreased after injury in 52 (49.05\%) patients. Agriculture injury has resulted in decreased work performance in 62 $(58.49 \%)$ patients. Out of 42 patients with fractures, 2 were lost to follow-up while one patient expired. The union was achieved in 32 of the 39 remaining patients $(82.05 \%)$. Thirty-four $(32.07 \%)$ patients had decreased range of motion in the injured part. Wound healing without infection was observed in eighty-four patients $(89.36 \%)$; whereas eight patients $(8.52 \%)$ had chronic infections in their wounds. There was only one fatality $(0.94 \%)$ in our study.

\section{Discussion}

Agriculture has made great strides in moving India from chronic food deficits to food surpluses and net food exports since the early 1990s. Most people $(49 \%)$ work in this sector. [8]. The accidents and injuries are natural hazards to everyone working in the farm environment and these happen as a culmination of multiple factors, e.g., man, machine, crop, toxic chemicals or environmental factors. Since the farming sector is unorganized, there is an absence of a nationwide repository on farm-related accidents and injuries, which could be useful to quantify the health and safety, and economic consequences. [9]. 
The majority of the studies in the literature report male preponderance in AI. This is primarily due to several males are involved in outdoor activities including agriculture. Tiwari et al (2001) have reported that males constituted $92.7 \%$ of the victims, whereas in our study male preponderance was observed with $82(77.35 \%)$ males and male to female ratio of $3.41: 1$. This increase in the proportion of females is probably due to a gap of almost 2 decades between the studies as well as the difference in social organization between two geographically separated regions.[10]. The highest numbers of victims were in the age group of 30-44 years $(45.1 \%)$ in the study by Tiwari et al against $(41.5 \%)$ in the present study.[10]. Maximum patients were in the age group of 30-45 years, meaning thereby that similar to the figures reported by Tiwari et al two decades ago, the age group most vulnerable to these injuries is the age group with the best productivity, which is a mix of experience and physical capability.[10]. In the present study there was no difference in the age of male and female patients ( $p$ value $=0.703)$.

Education plays a major role on both the fronts of employment and income. In developing countries like India, low education levels are associated with more labour-intensive work and thus more prone to work-related injuries. Most of the patients (40; $37.74 \%$ ) were illiterate (No formal education) and farmers 38 (35.84\%) \& farm laborers 26 (24.52\%). Forty-five $(42.46 \%)$ patients had no land holding, $20(18.86 \%)$ had less than 2 acres of land, thus already living on meagre sources of income. Any injury to the family member may severely jeopardize already strained livelihood; more so fiftyfour $(50.95 \%)$ patients were living in a joint family, thus impacting not only the injured but also the whole family. Poor light arrangements, unskilled workers, drug/alcohol abuse, fatigue, poor designing and lack of orientation to work on the agricultural machines are the contributory factors to AI.[11]. The present study also substantiates these findings, as thirty-five $(33.02 \%)$ patients were unskilled workers at the time of injury, 21 (19.81\%) were under the influence of alcohol/drugs, while 29 $(27.35 \%)$ were fatigued at the time of injury. Eighty-seven patients (82.07\%) had worked for more than three hours before the injury. Seasonal variations have been observed in the AI.[11] Sixtynine $(65.10 \%)$ patients presented in the winter season, $27(25.47 \%)$ in the present study; but chaff cutter injuries were observed all around the year as dairy farming is a perennial activity.
Mohan and Patel (1992) in a study conducted in nine contiguous villages in the Sonipat district of Haryana state reported that maximum injuries occurred while working with spades (24\%), followed by sickles $(23 \%)$, bullock carts and manually operated chaff cutters ( $6 \%$ each), and poweroperated chaff cutters, tractors, and diesel engines (5\% each).[12]. Tiwari et al (2001) have reported that of the total incidents, $77.6 \%$ were due to farm machinery, $9(11.8 \%)$ were due to hand tools, and $8(10.6 \%)$ were due to other sources like snakes, wells, agricultural chemicals, etc. Tractor-related incidents were most common $(46.0 \%)$, followed by threshers $(14.5 \%)$, sickles $(10.5 \%)$, electric motors and pump sets (7.9\%).[10]. Patel et al (2010) in a retrospective study (1996-2000) have reported that out of total injuries, $57(53.77 \%)$ were farm machinery-related, $43(40.56 \%)$ were due to hand tools and six (5.66\%) were due to other sources. [13].

Das et al (2014) have reported from a study in Bengal that machine and hand tools were involved in the major number of farm injuries and among the farm machinery, overturn of a tractor with a heavy load causes a major number of accidents.[14]. Bhattarai et al (2016) reported farm injuries from a village in the Himalayan country of Nepal, where hand tool was a frequent mode of injury among the respondents.[15]. In our study the machinery used in farming was the main etiological factor causing injury $(60 ; 56.60 \%)$. Most patients sustained injury due to chaff/fodder cutting machine 40 (37.73\%) (Fig. 1) and followed by thresher 11 (10.37\%) (Fig. $2)$. This is because with time there has been increased mechanization of farming as well as that due to the geographical and socio-economic advantage of northern Indian agrarian states there is a predilection towards the use of more mechanical aides in farming as compared to hand tools. Singh et al (2005) in a prospective study analyzing wheat thresher agricultural injuries during the wheat harvesting season of March to June, 2003, have reported that upper limb injuries were most commonly involved and a significant number resulted in the amputation of some parts. [11]. Grandizio et al have reported 35\% upper extremity predominantly resulting in fractures of the phalanges and/or forearm bones. [16]. In the present study too, in most of the cases, the upper limb was involved in the form of amputations and fractures. In the cohort most common injury was upper limb injury (80 patients; $75.47 \%$ ), followed by lower limb injury (19 patients; $17.93 \%)$. 
These figures are significant and because while lower limbs, mainly provide stability and locomotion, it is the upper limbs that are actively and closely involved with the moving mechanical parts of farming machinery thereby making them more prone to injuries as well as more severity of injuries sustained. In the present study amputations were the most common injuries (50 patients; $47.16 \%)$, followed by fracture (closed/open)/dislocation in 40 patients (37.62\%). The upper limb was involved most commonly and common injuries were amputations at different levels. The most common level of amputation was at fingers, which were present in 25 patients (23.58\%). Grandizio et al concluded that patients sustaining agricultural upper extremity injuries have longer lengths of stay and more frequently require surgery and hospital readmissions occur frequently in patients with these injuries. [16].

Agricultural machinery causes lots of cutting and crushing of soft tissues and the resulting injuries are often contaminated with dust, grease, and organic particles (Fig. 3). The vitality of the tissues has been always doubtful, thus are more prone to infections and tetanus. Antibiotic therapy should be instituted as early as possible. The patient's tetanus status must be documented and supplementary injections are given if necessary. These injuries should be managed early to avoid secondary complications. Sixty-one (57.54\%) patients reached the hospital within 2 hours of injury, 28 (26.41\%) reported in 2-3 hours, and 17 (16.03\%) reached after 3 hours of injury. The early reporting to the Centre helped us to manage these injuries early and more effectively; thus minimizing secondary complications viz. infections and improving the outcome.

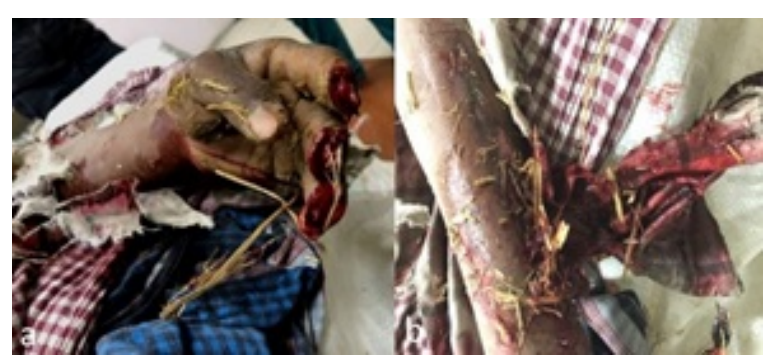

\section{Figure 3:}

01. Shows grossly contaminated traumatic amputation at finger level after thresher injury. The loose sleeve of the garment got entangled in the machine and pulled the limb into the inlet of the machine.
01. Shows gross contamination of forearm lacerated wound with organic debris.

Ninety-four (88.68\%) patients required surgical intervention and $12(11.32 \%)$ were managed conservatively in the present study. Conservative management was mainly done in form of crepe bandage, POP cast and medical therapy for back pain patients in the form of NSAIDs and muscle relaxants. Revision amputation was the most common (27 patients; 25.47\%) surgical intervention required and $\mathrm{K}$-wire fixation of fractures was done in $23(21.69 \%)$ patients. The surgery rate as well as the rates of readmission, revision surgery and the total length of hospital stay are dictated by the complexity of the injuries. As the farm machinery-related injuries involve dirt, grease, grime, organic material, etc. in combination with open injuries, the extent, duration, the number of surgical interventions and hospital stay are naturally increased.

Bhattarai et al (2016) reported that out of a total of $222,64.3 \%$ of respondent injured workers took some time off work due to injury. [15]. In the present study, household activities were decreased after injury in $52(49.05 \%)$ patients, whereas there was decreased work performance in 62 (58.49\%) patients; all these have an impact on quality of life and income post-injury. Out of 42 patients with fractures, 2 were lost to follow-up while one patient expired. The union was achieved in 32 of the 39 remaining patients $(82.05 \%)$. Thirty-four $(32.07 \%)$ patients had decreased range of motion in the injured part. Wound healing without infection was observed in eighty-four patients $(89.36 \%)$; whereas eight patients $(8.52 \%)$ had chronic infections in their wounds.

Nag and Nag (2004) have reported that most of the fatal accidents resulted from machinery, with the annual fatality rate estimated at 22 per 100,000 farmers. [9]. Patel et al (2010) in a retrospective study (1996-2000) have reported a $9 \%$ fatality in a survey of six blocks Etawah district of Uttar Pradesh. [13]. This resulted in a substantial economic burden.[9,13]. Mohan and Patel (1992) estimated that agricultural activities caused about 5,000 to 10,000 deaths, 15,000 to 20,000 amputations, and 150,000 to 200,000 serious injuries every year in the three North Indian agrarian states of Haryana, Punjab, and Uttar Pradesh alone. [12].

In contrast, there was only one fatality $(0.94 \%)$ in our study. 
While the state of Haryana is a predominantly agricultural state and the Federal as well as State governments run programs related to farming activities including the use of machinery in agricultural activities, most of the programs are static and passive. There is no active involvement of governmental or scientific bodies with the farming community, nor is there an active program of regular, systematic study and analysis of farmingrelated injuries and their subsequent repercussions. Over the decades, several pieces of legislation about farming injuries have come out at both Federal and State levels, but these are more focused on financial compensation rather than prevention, mitigation, and rehabilitation. The scientific assessment of health issues and their remedies about agricultural injuries is not at par with that in other parts of the world like the UK, USA, Canada, etc. Although our study is limited by the fact that it is confined to a part of Northern Indian agricultural plains and the data is not representative of the diverse geological and demographic entity that India is, it can highlight the dangers of technical illiteracy combined with physical and resource inadequacy when dealing with complicated machinery and equipment. What is needed is a robust program with the active involvement of Government agencies and scientific bodies with the farming community at the village and individual level. This should include information, communication, education, and training of the farmhands as well as a collection of data and feedback from the farming community to help design well, more efficient, more ergonomic and safer agricultural machinery. There is also a need to inculcate best and safer practices in the use of agricultural tools and machinery. These programs need to be adapted to local needs, socio-economic and educational status as well as cultivated crops and farming practices. In addition to designing safer machinery and equipment, the collected scientific data would enable the development of more advanced training programs, thereby reducing the injuries and their adverse socio-economic impact on individuals, families, as well as society.

\section{Conclusions}

There is profound suffering and loss in the farming community due to AI. Prevention is the best policy for these mutilating injuries. This can be done by bringing behavioural change in the agricultural workers by giving them proper \& timely education and training to work on agricultural machinery and farms.
In addition, improvisation and modification in the machinery should be done as per the local requirements, for the safe use and prevention of AI. The present study highlights the need for a robust surveillance and data analysis leading to better design of farming machinery and equipment, more relevant education and training systems, stronger legislations as well as a comprehensive rehabilitative program aimed at reducing the socioeconomic burden caused by agricultural injuries.

\section{Reference}

01. Naeini H S, Karuppiah K, Tamrin S B, Dalal K. Ergonomics in agriculture- an approach in prevention of work-related musculoskeletal disorders (WMSDs). Journal of Agriculture and Environmental Sciences. 2014;3(2)33-51. [Crossref][PubMed][Google Scholar]

02. Kim I J. Accidents and accident prevention in the agricultural industry- ergonomic engagement. J Ergon. 6;3(2016). [Crossref][PubMed][Google Scholar]

03. Food and agriculture organization of the United Nations. India at a glance [Online]. Available at [Article] [Crossref][PubMed][Google Scholar]

04. Government of Haryana. Demography [Online]. (2020). Available at [Article] [Crossref][PubMed] [Google Scholar]

05. Indian Council of Agricultural Research (2007). State specific technological Interventions for higher agricultural growth [Online]. Available at [Article] [Crossref][PubMed][Google Scholar]

06. Directorate of Economics and Statistics, Department of Agriculture, Cooperation \& Farmers Welfare, Ministry of Agriculture \& Farmers Welfare, Government of India (2019). Agricultural statistics at a glance (2018) [Online]. Available at [Article] [Crossref][PubMed][Google Scholar]

07. McClure SK, Shaughnessy WJ. Farm-related limb amputations in children. J Pediatr Orthop. 2005 Mar-Apr;25(2)133-7. doi: 10.1097/01.bpo.0000149864.42777.96 [Crossref] [PubMed][Google Scholar]

08. World Bank Group. India Systematic Country Diagnostic- Realizing the Promise of Prosperity. World Bank. 2018. [Crossref][PubMed][Google Scholar] 
09. Nag PK, Nag A. Drudgery, accidents and injuries in Indian agriculture. Ind Health. 2004 Apr;42(2)149-62. doi: 10.2486/indhealth.42.149 [Crossref][PubMed][Google Scholar]

10. Tiwari PS, Gite LP, Dubey AK, Kot LS. Agricultural injuries in Central India: nature, magnitude, and economic impact. J Agric Saf Health. 2002 Feb;8(1)95-111. doi: 10.13031/2013.7221 [Crossref][PubMed][Google Scholar]

11. Singh R, Sharma AK, Jain S, Sharma SC, Magu NK. Wheat thresher agricultural injuries- a byproduct of mechanised farming. Asia Pac J Public Health. 2005;17(1)36-9. doi: 10.1177/101053950501700109 [Crossref][PubMed] [Google Scholar]

12. Mohan D, Patel R. Design of safer agricultural equipment: Application of ergonomics and epidemiology. International Journal of Industrial Ergonomics. 1992;10(4)301-309. [Crossref] [PubMed][Google Scholar]
13. Patel $S$ K, M R Varma, Adarsh Kumar. "Agricultural injuries in Etawah district of Uttar Pradesh in India". Safety Science. 48;2(2010)222229. [Crossref][PubMed][Google Scholar]

14. Das B. Agricultural work related injuries among the farmers of West Bengal, India. Int J Inj Contr Saf Promot. 2014;21(3)205-15. doi: 10.1080/17457300.2013.792287 [Crossref] [PubMed][Google Scholar]

15. Bhattarai D, Singh SB, Baral D, Sah RB, Budhathoki SS, Pokharel PK. Work-related injuries among farmers- a cross-sectional study from rural Nepal. J Occup Med Toxicol. 2016 Oct 26;11;48. doi: 10.1186/s12995-016-0137-2 [Crossref] [PubMed][Google Scholar]

16. Grandizio LC, Wagner B, Graham J, Klena JC. Upper Extremity Trauma Resulting From Agricultural Accidents- Mechanism and Severity for Patients With and Without Upper Extremity Injury. Hand (N Y). 2018 Jul;13(4)384-390. doi: 10.1177/15589 44717715140 [Crossref][PubMed][Google Scholar] 